\title{
THE FORMATION MECHANISM OF ASSEMBLED COMPLEXES BRIDGED BY 1,3-BIS(4-PYRIDYL)PROPANE
}

\author{
Haruka Dote ${ }^{\mathrm{a}}$, Hiroki Yasuhara ${ }^{\mathrm{a}}$, Satoru Nakashima ${ }^{\mathrm{a}, \mathrm{b}^{*}}$ \\ ${ }^{a}$ Department of Chemistry, Graduate School of Science, Hiroshima University \\ 1-3-1 Kagamiyama, Higashi-Hiroshima, Hiroshima 739-8526, Japan \\ ${ }^{b}$ Natural Science Center for Basic Research and Development (N-BARD), Hiroshima University \\ 1-4-2 Kagamiyama, Higashi-Hiroshima, Hiroshima 739-8526, Japan \\ "e-mail: snaka@hiroshima-u.ac.jp
}

\begin{abstract}
Several types of differently coloured crystals (light blue, blue and red) were obtained in the synthesis of assembled complex of mixed crystals with three metals by using solvent diffusion method. The mechanism of obtaining the assembled complexes is discussed based on the structure and colour change. The red crystal has 2D interpenetrated structure. The light-blue samples were $\left[\mathrm{H}_{2}(\mathrm{bpp})\right]\left[\mathrm{M}(\mathrm{NCS})_{4}\right]$ and they were built up spirally. The blue samples were $\mathrm{M}(\mathrm{NCS})_{2}(\mathrm{bpp})$ and they formed 1D chain. $\left[\mathrm{H}_{2}(\mathrm{bpp})\right]\left[\mathrm{M}(\mathrm{NCS})_{4}\right]$ changed to $1 \mathrm{D}$ chain polymer $\left(\mathrm{M}(\mathrm{NCS})_{2}(\mathrm{bpp})\right)$ by releasing HNCS from the cation and anion in a reaction vessel. Inductively Coupled Plasma Atomic Emission Spectroscopy, Electrospray Ionization Mass Spectrometry and X-Ray diffraction were used for characterization of the obtained complexes.
\end{abstract}

Keywords: mixed crystal, assembled complex, 1,3-bis(4-pyridyl)propane, crystal formation.

Received: December 2015/ Revised final: February 2016/ Accepted: February 2016

\section{Introduction}

Self-assembled coordination polymers containing transition metal ions and organic bridging ligands have attracted intensive interest in virtue of their potential abilities for selective inclusion and transformation of ions and molecules [1]. Up to now various assembled structures have been reported [2-8]. We have studied iron complexes bridged by 1,3-bis(4-pyridyl)propane (bpp), containing three methylene groups, by using single crystal X-ray diffraction analysis, Mössbauer spectroscopy and Superconducting Quantum Interference Device (SQUID) measurements. Fe(NCX) ${ }_{2}(\mathrm{bpp})_{2}$ $\left(\mathrm{X}=\mathrm{S}\right.$, Se and $\left.\mathrm{BH}_{3}\right)$ had a 2D interpenetrated structure and the $\mathrm{NCBH}_{3}$ complex showed a spin-crossover phenomenon [9]. When the benzene is enclathrated, the structure becomes 1D chain [10]. Recently, we discussed the spin state of the mixed crystals of iron with zinc or cobalt ion in the 2D interpenetrated structure for the assembled complexes bridged by bpp, and we revealed that NCSe complex had a lowered spin state, in comparison with pure Fe complex, because iron atom is forced to reduce its radius in the zinc or cobalt complexes having smaller unit cell [11].

Herein we report on the synthesis of mixed crystals including zinc, cobalt, and iron atoms. Several types of crystals appeared and the colour changed in the reaction medium. The mechanism of obtaining the assembled complexes is put into discussion on the basis of structure and colour modification.

\section{Experimental}

Synthesis

Mixed crystals including three metals were obtained by solvent diffusion method. Solvent diffusion method- 1$)$ bottom layer: metal salts $\left(\left(\mathrm{FeSO}_{4} \cdot 7 \mathrm{H}_{2} \mathrm{O}(0.33 \mathrm{mmol})+\mathrm{ZnSO}_{4} \cdot 6 \mathrm{H}_{2} \mathrm{O}(0.33 \mathrm{mmol})+\mathrm{CoSO}_{4} \cdot 7 \mathrm{H}_{2} \mathrm{O}(0.33 \mathrm{mmol})\right), \mathrm{NaNCS}\right.$ $(2 \mathrm{mmol})$ and $\mathrm{L}$-ascorbic acid to avoid oxidation in $\left.\mathrm{H}_{2} \mathrm{O}(20 \mathrm{~mL}) ; 2\right)$ middle layer: $\mathrm{H}_{2} \mathrm{O}(20 \mathrm{~mL})$ and cyclohexane $(20 \mathrm{~mL})$; $3)$ top layer: bpp $(2 \mathrm{mmol})$ in EtOH $(1 \mathrm{~mL})$ and cyclohexane $(19 \mathrm{~mL})$. Light-blue crystals appeared about 4 hours after the setting and they decreased time to time because of dissolution. Precipitates were mixtures of light-blue crystals, blue crystals, and red crystals. Light-blue crystals were dissolved in acetone and they could be isolated. Anal. found (calc.)\%: for $\left\{\left[\mathrm{H}_{2}(\mathrm{bpp})\right]\left[\mathrm{M}(\mathrm{NCS})_{4}\right]\right\}_{\mathrm{n}}, \mathrm{C}, 41.67$ (41.08); H, 3.21 (3.24); N 16.74 (16.91); S, 24.76 (25.81)( $\left.\mathrm{M}^{2} \mathrm{Fe}_{0.06} \mathrm{Zn}_{0.87} \mathrm{Co}_{0.07}\right)$. Single crystals of blue crystals were picked up from the reaction vessel. Anal. found (calc.)\%: for $\left\{\mathrm{M}(\mathrm{NCS})_{2}(\mathrm{bpp})\right\}_{\mathrm{n}}$ (blue crystal), C, 47.79 (47.43); H, 3.64 (3.72); N 14.80 (14.75); S, 16.89 (16.89)( $\left.\mathrm{M}=\mathrm{Fe}_{0.01} \mathrm{Zn}_{0.95} \mathrm{Co}_{0.04}\right)$. Anal. found (calc.)\%: for red crystal, C, 58.65 (58.47); H, 4.67 (4.91); N 14.72 (14.62); S, 11.20 (11.15) (M= $\left.\mathrm{Fe}_{0.20} \mathrm{Zn}_{0.63} \mathrm{Co}_{0.17}\right)$.

Light-blue crystals were selectively obtained when the diluted $\mathrm{HNO}_{3}(0.16 \mathrm{M}, 20 \mathrm{~mL})$ was added to the water phase. Single crystals appeared in the bottom.

$\mathrm{Zn}$ complex was obtained by solvent diffusion method. Solvent diffusion method: bottom layer; $\mathrm{ZnSO}_{4} \cdot 6 \mathrm{H}_{2} \mathrm{O}$ (0.2 mmol), NaNCS (or KNCS) $(0.4 \mathrm{mmol})$ in $\mathrm{H}_{2} \mathrm{O}(20 \mathrm{~mL})$, middle layer; $\mathrm{H}_{2} \mathrm{O}(20 \mathrm{~mL})$ and EtOH $(20 \mathrm{~mL})$, top layer; bpp $(0.2 \mathrm{mmol})$ in EtOH $(20 \mathrm{~mL})$. Crystals appeared about 1 week after the setting.

\section{ICP-AES analyses}

The metal fraction, Fe:Zn:Co was determined by Inductively Coupled Plasma Atomic Emission Spectroscopy 
(ICP-AES) at SPS3510 spectrometer (SII NanoTechnology Inc.). Calibration curves were drawn by measuring intensity of $1,0.5,0.1$, and $0.01 \mathrm{ppm}$ for iron and zinc standard solution and 0.994, 0.497, 0.099, and 0.050 ppm for cobalt standard solution and ultrapure water. Scan range of iron, zinc, and cobalt was around 238.204, 202.548, and 228.616 $\mathrm{nm}$, respectively.

\section{ESI-MS measurements}

Electrospray Ionization Mass Spectrometry (ESI-MS) was performed using LTQ Orbitrap XL spectrometer (Thermo Fisher Scientific).

\section{$X$-ray diffraction measurements}

The powder X-ray diffraction patterns were measured on a Rigaku RAD-X system using $\mathrm{Cu}-\mathrm{K} \alpha$ radiation and employing a scan rate of $5.0^{\circ} / \mathrm{min}$, step of $0.02^{\circ}$, and region from 5.0 to $60.0^{\circ}$. All measurements were performed under air at room temperature (RT).

Zn complex and light-blue crystals were obtained as a single crystal, and the structures were determined by single crystal X-ray structural analysis. The crystal data can be obtained free of charge from the Cambridge Crystallographic Data Centre via www.ccdc.cam.ac.uk/data_request/cif. (CCDC:1433079 and 1455350).

\section{Results and discussion}

Figure 1 shows powder X-ray diffraction patterns of pure iron complex and mixed metal complexes. They revealed that the red crystals has $2 \mathrm{D}$ interpenetrated structure, which is similar to the structure of Fe(NCS) $)_{2}(\mathrm{bpp})_{2}$. The light-blue and blue crystals showed new structure and structural change in the reaction vessel.

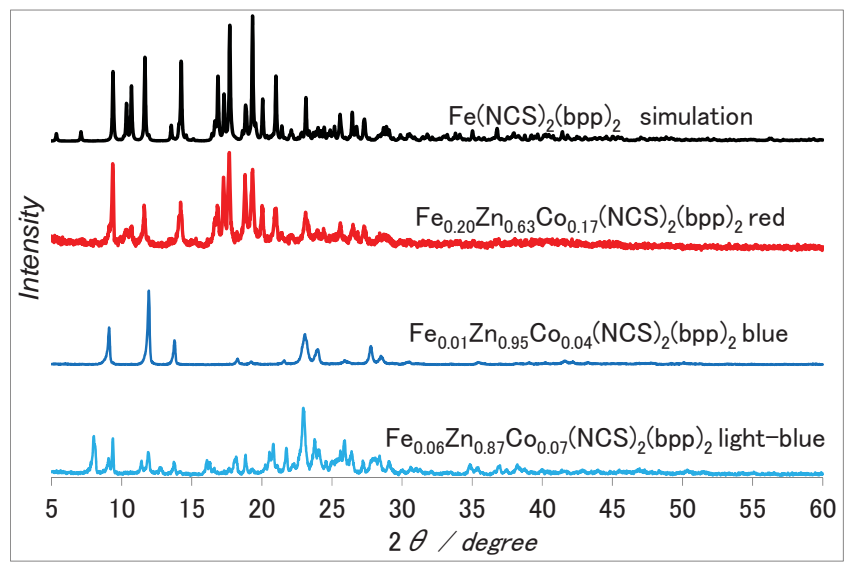

Figure 1. Powder X-ray diffraction patterns of Fe(NCS) ${ }_{2}(\mathrm{bpp})_{2}$, red, blue and light-blue mixed crystals.

Figure 2 shows ESI mass spectra of the light-blue crystals measured in the positive and negative ion modes (measurements and simulations). These results along with elemental analysis data prove the composition $\left[\mathrm{H}_{2}(\mathrm{bpp})\right]$ $\left[\mathrm{M}(\mathrm{NCS})_{4}\right]$. Figure 3 shows Oak Ridge Thermal-Ellipsoid Plot Program (ORTEP) drawing and packing view of lightblue crystal. Crystal data are shown in Table 1. Selected bond lengths and angles are shown in Table 2.
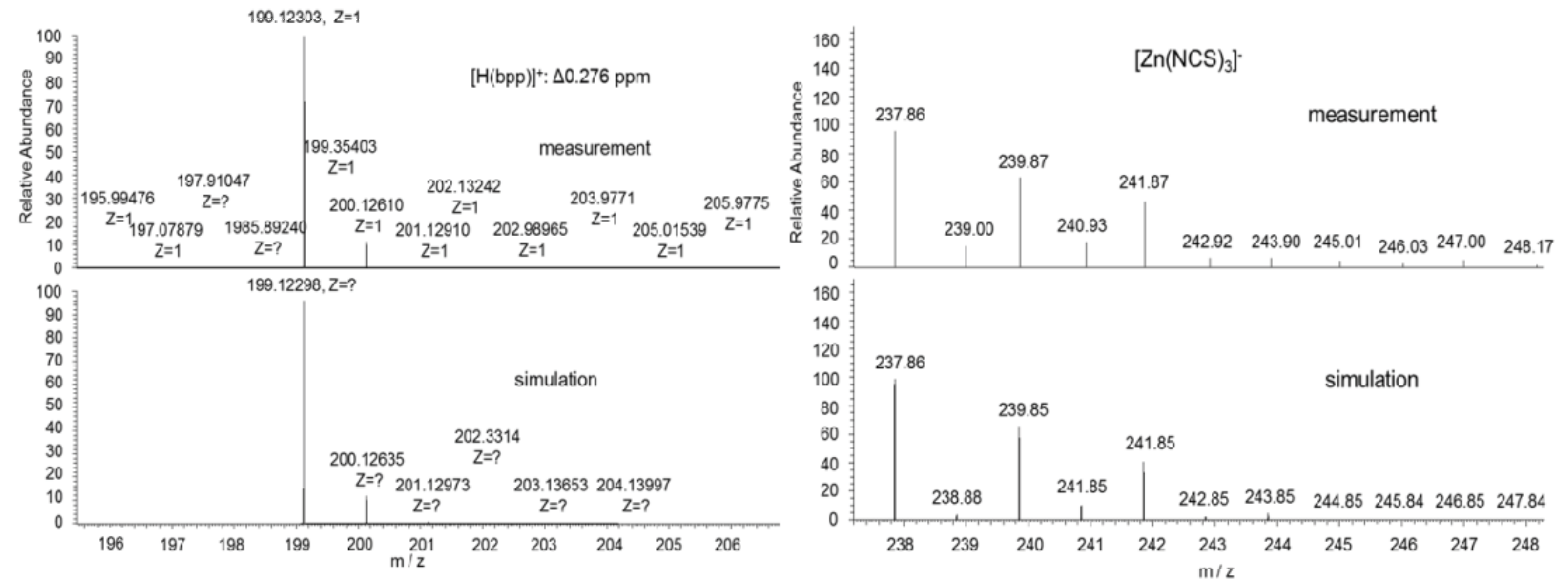

Figure 2. ESI mass spectra of the light-blue crystal measured in the positive and negative ion modes (measurements and simulations). 
Crystal data of light-blue crystal ([H $\left.\left(\mathrm{H}_{2}(\mathrm{bpp})\right]\left[\mathrm{Fe}_{0.06} \mathrm{Zn}_{0.87} \mathrm{Co}_{0.07}(\mathrm{NCS})_{4}\right]\right)$.

\begin{tabular}{cc}
\hline Parameter & Value \\
Formula & $\mathrm{C}_{13} \mathrm{H}_{16} \mathrm{~N}_{2}+\mathrm{C}_{4} \mathrm{~N}_{4} \mathrm{~S}_{4} \mathrm{Zn}$ \\
Temperature & $\mathrm{RT}$ \\
Crystal system & Orthorhombic \\
Space Group & $P 2_{1} 2_{1} 2$ \\
$\mathrm{Z}$ & 4 \\
$\mathrm{a} / \AA$ & $21.7042(7)$ \\
$\mathrm{b} / \AA$ & $22.002(3)$ \\
$\mathrm{c} / \AA$ & $4.639(3)$ \\
Volume/ $/ \AA^{3}$ & $2215.3(16)$ \\
$R$ & 0.0316 \\
$w R$ & 0.0749 \\
Goodness of Fit & 1.042 \\
\hline
\end{tabular}

Selected bond lengths and angles of light-blue crystal ([H $\left.(\mathrm{bpp})]\left[\mathrm{Fe}_{0.06} \mathrm{Zn}_{0.87} \mathrm{Co}_{0.07}(\mathrm{NCS})_{4}\right]\right)$.

\begin{tabular}{cc}
\hline$\left[\mathrm{H}_{2}(\mathrm{bpp})\right]\left[\mathrm{Zn}(\mathrm{NCS})_{4}\right]$ & Bond lengths or angles \\
\hline $\mathrm{Zn}-\mathrm{N} 1(\mathrm{NCS}) / \AA$ & $1.951(4)$ \\
$\mathrm{Zn}-\mathrm{N} 2(\mathrm{NCS}) / \AA$ & $1.954(4)$ \\
$\mathrm{Zn}-\mathrm{N} 3(\mathrm{NCS}) / \AA$ & $1.960(4)$ \\
$\mathrm{Zn}-\mathrm{N} 4(\mathrm{NCS}) / \AA$ & $1.971(3)$ \\
$\mathrm{S} 1-\mathrm{S} 3{ }^{\prime} / \AA$ & $3.4550(16)$ \\
$\mathrm{S} 2-\mathrm{S} 4{ }^{\prime} / \AA$ & $3.5058(14)$ \\
$\mathrm{S} 2{ }^{\prime}-\mathrm{N} 5(\mathrm{bpp}) / \AA$ & $3.407(4)$ \\
$\mathrm{S} 4-\mathrm{N} 5{ }^{\prime}(\mathrm{bpp}) / \AA$ & $3.403(4)$ \\
$\mathrm{S} 3{ }^{\prime}-\mathrm{N} 6(\mathrm{bpp}) / \AA$ & $3.405(4)$ \\
$\mathrm{S} 1-\mathrm{N} 6(\mathrm{bpp}) / \AA$ & $3.423(4)$ \\
$\mathrm{N} 1-\mathrm{Zn}-\mathrm{N} 2{ }^{\circ}$ & $107.72(14)$ \\
$\mathrm{N} 1-\mathrm{Zn}-\mathrm{N} 3 /^{\circ}$ & $115.57(18)$ \\
$\mathrm{N} 1-\mathrm{Zn}-\mathrm{N} 4{ }^{\circ}$ & $104.93(14)$ \\
$\mathrm{N} 2-\mathrm{Zn}-\mathrm{N} 3{ }^{\circ}$ & $107.91(15)$ \\
$\mathrm{N} 2-\mathrm{Zn}-\mathrm{N} 4{ }^{\circ}$ & $115.56(17)$ \\
$\mathrm{N} 3-\mathrm{Zn}-\mathrm{N} 4{ }^{\circ}$ & $105.42(14)$ \\
\hline
\end{tabular}

Metals are tetrahedrally coordinated by four NCS anions to become $\left[\mathrm{M}(\mathrm{NCS})_{4}\right]^{2-}$ and bpp is doubly protonated$\left[\mathrm{H}_{2}(\mathrm{bpp})\right]^{2+}$. Thus, the whole composition becomes $\left[\mathrm{H}_{2}(\mathrm{bpp})\right]\left[\mathrm{M}(\mathrm{NCS})_{4}\right]$, and this is a mononuclear complex. This structure organisation explains the better dissolution of this sample in the solvent, as compared with blue and red crystals, respectively. The packing view in one plane is shown in Figure $3(\mathrm{~b})$. $\left[\mathrm{H}_{2}(\mathrm{bpp})\right]^{2+}$ is surrounded by four $\left[\mathrm{M}(\mathrm{NCS})_{4}\right]^{2-}$, $\left[\mathrm{M}(\mathrm{NCS})_{4}\right]^{2-}$ in turn, being also surrounded by four $\left[\mathrm{H}_{2}(\mathrm{bpp})\right]^{2+}$ in the same plane. The fragments $\left[\mathrm{H}_{2}(\mathrm{bpp})\right]$ are placed almost perpendicular to each other. This plane is stacked to each other to form crystal (Figure 3(c)), the structure being similar to $\left[4,4^{\prime}\right.$-bipyH $\left.\mathrm{H}_{2}\right]\left[\mathrm{Zn}(\mathrm{NCS})_{4}\right][13]$. Each sulphur atom of the $\left[\mathrm{Zn}(\mathrm{NCS})_{4}\right]^{2-}$ anion has a weak S...S contact with a sulphur atom from an adjacent $\left[\mathrm{Zn}(\mathrm{NCS})_{4}\right]^{2-}$ anion. The distances of these contacts being $3.4550(16)$ or $3.5058(14) \AA$, they are slightly shorter than that in $\left[4,4^{\prime}\right.$-bipyH $\left.H_{2}\right]\left[\mathrm{Zn}(\mathrm{NCS})_{4}\right][13](3.63 \AA)$, and also slightly shorter than the sum of the van der Waals radii of two sulphur atoms, indicating weak interaction [14]. The frame constructed by weak S...S contact was built spirally. The sulphur atoms also form hydrogen bonds with the $\left[\mathrm{H}_{2}(\mathrm{bpp})\right]^{2+}$ cations. The distances are

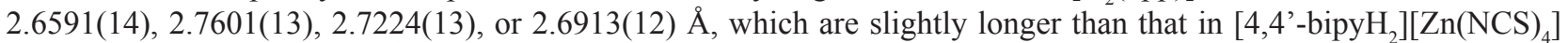
[13] $(2.404(3) \AA)$. This is due to the difference that $\left[\mathrm{H}_{2}(\mathrm{bpp})\right]^{2+}$ is placed in centre between anion, while $\left[4,4^{\prime}-\mathrm{bipyH}_{2}\right]^{2+}$ approaches the one side of anion. 

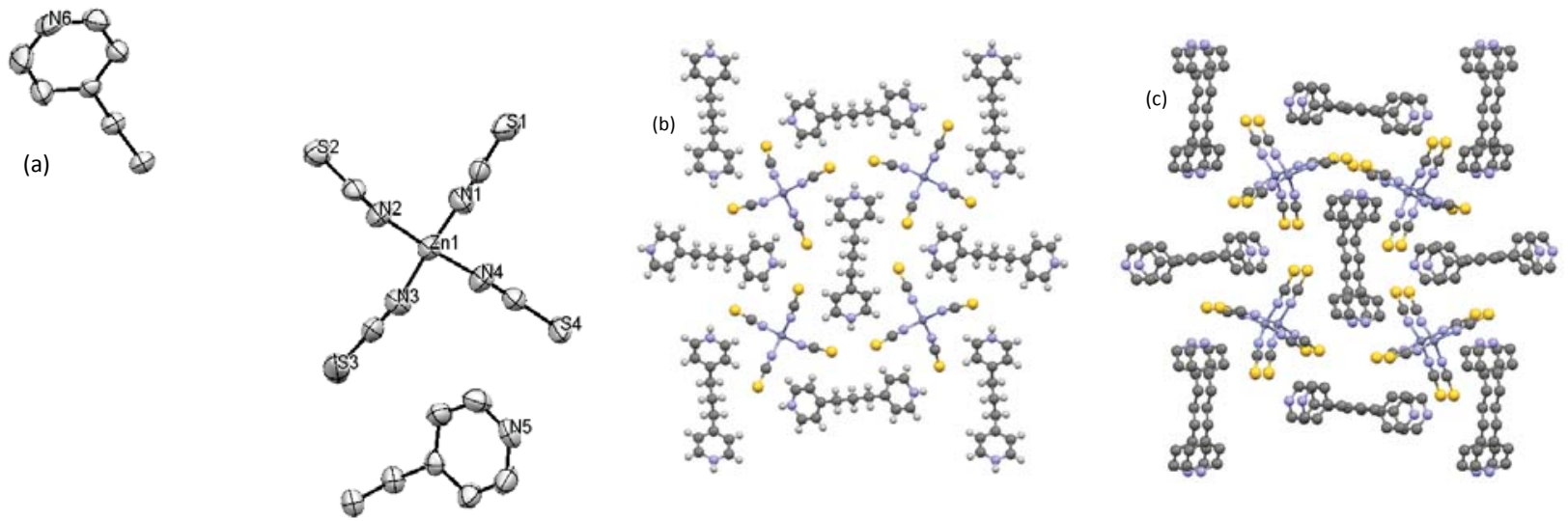

Figure 3. Crystal structure of light-blue crystal ([H $\left.(\mathrm{bpp})]\left[\mathrm{Fe}_{0.06} \mathrm{Zn}_{0.87} \mathrm{Co}_{0.07}(\mathrm{NCS})_{4}\right]\right)$.

(a)- ORTEP drawing, (b)- packing view in one plane, and (c)- packing view.

Blue sample could not be isolated as a single crystal, but as an aggregation of very small crystals. By comparing the powder X-ray diffraction patterns (Figure 4) and on the basis of elemental analysis data, it was confirmed, that blue crystals and pure zinc complex $\left(\mathrm{Zn}(\mathrm{NCS})_{2}(\mathrm{bpp})\right)$ have identical structures. It can be considered that the structures are controlled by the $\mathrm{Zn}$ metal. The structure of $\mathrm{Zn}(\mathrm{NCS})_{2}(\mathrm{bpp})$ was determined by single X-ray structural analysis. Crystal data are shown in Table 3. Selected bond lengths and angles are shown in Table 4. Figure 5(a) shows ORTEP drawing of pure zinc complex. Zn is tetrahedrally coordinated by one bpp and two NCS to form 1D chain. The 1D chain is shown in Figure 5 (b). This is not an ionic complex, but neutral 1D chain polymer.

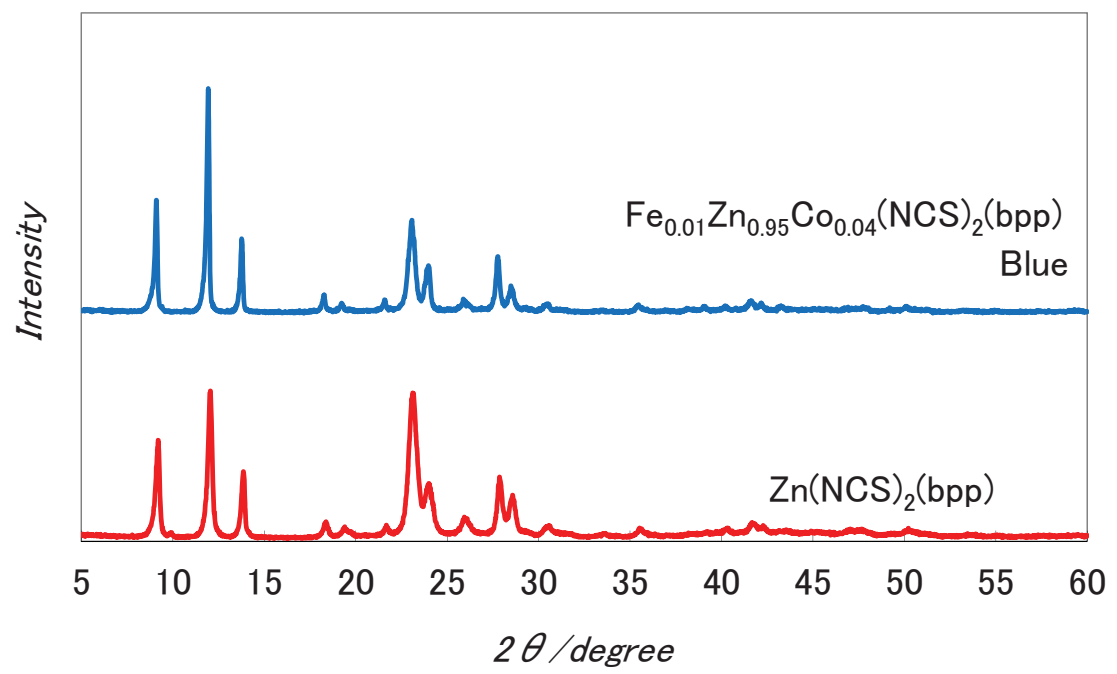

Figure 4. Comparison of powder X-ray diffraction patterns of $\mathrm{Fe}_{0.01} \mathrm{Zn}_{0.95} \mathrm{Co}_{0.04}(\mathrm{NCS})_{2}(\mathrm{bpp})$ and $\mathrm{Zn}(\mathrm{NCS})_{2}$ (bpp).
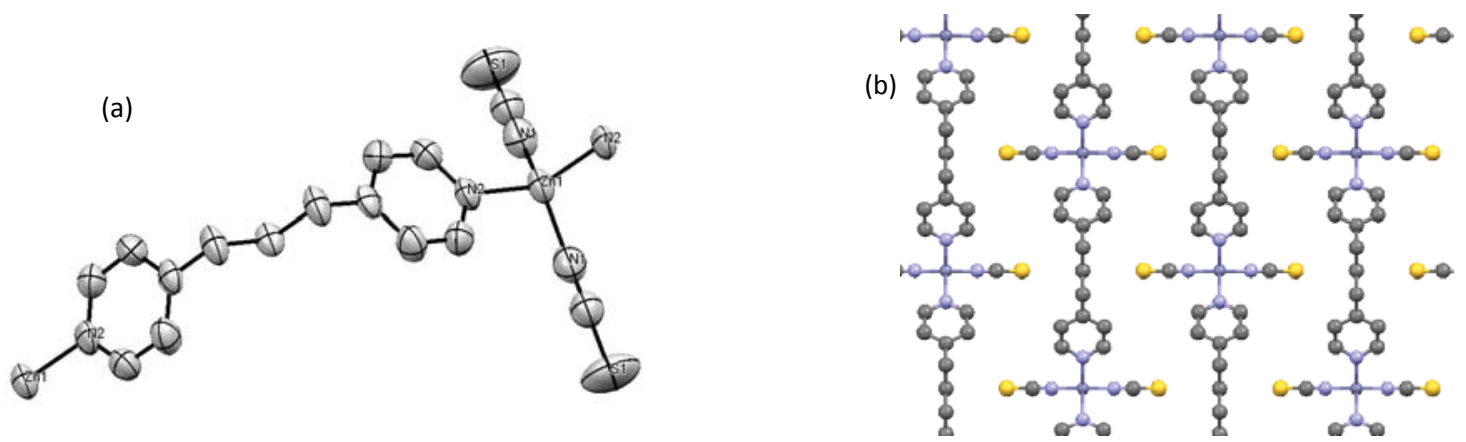

Figure 5. Crystal structure of Zn(NCS) ${ }_{2}$ (bpp).

(a)- ORTEP drawing and (b)- packing view. 
Crystal data of Zn(NCS) $)_{2}$ (bpp).

\begin{tabular}{|c|c|}
\hline Parameter & Value \\
\hline \multicolumn{2}{|c|}{$\begin{array}{c}\text { Formula } \\
\mathrm{C}_{15} \mathrm{H}_{14} \mathrm{~N}_{4} \mathrm{~S}_{2} \mathrm{Zn}\end{array}$} \\
\hline Temperature & RT \\
\hline Crystal system & Orthorhombic \\
\hline Space Group & $\mathrm{Imm} 2$ \\
\hline $\mathrm{Z}$ & 2 \\
\hline $\mathrm{a} / \AA$ & $12.859(6)$ \\
\hline $\mathrm{b} / \AA$ & $14.891(7)$ \\
\hline $\mathrm{c} / \AA$ & $4.779(2)$ \\
\hline Volume $/ \AA^{3}$ & $915.1(7)$ \\
\hline$R$ & 0.0533 \\
\hline$w R$ & 0.1300 \\
\hline Goodness of Fit & 1.139 \\
\hline
\end{tabular}

The light-blue crystals are easily dissolved in acetone. The light-blue crystals changed to blue in the reaction vessel in acetone solution. Usually, metals and ligands gather to each other to form a stable assembled structure in the synthetic process of assembling complexes. In the present study, it was shown that at the first stage the ionic crystals are obtained and subsequently, the crystal changed to more stable assembled structure. It is considered that initially $\left[\mathrm{H}_{2}(\mathrm{bpp})\right]^{2+}$ and $\left[\mathrm{M}(\mathrm{NCS})_{4}\right]^{2-}$ are formed in water or EtOH, which then precipitate as $\left[\mathrm{H}_{2}(\mathrm{bpp})\right]\left[\mathrm{M}(\mathrm{NCS})_{4}\right]$. This is not the most stable structure in the reaction vessel. It undergoes modifications, to form 1D polymer chain structure by releasing HNCS from the cation and anion.

Table 4

Selected bond lengths and angles of $\mathrm{Zn}(\mathrm{NCS})_{2}(\mathrm{bpp})$.

\begin{tabular}{cc}
\hline $\mathrm{Zn}(\mathrm{NCS})_{2}($ bpp $)$ & Bond lengths or angles \\
\hline $\mathrm{Zn}-\mathrm{N} 1(\mathrm{NCS}) / \AA$ & $1.929(11)$ \\
$\mathrm{Zn}-\mathrm{N} 2(\mathrm{bpp}) / \AA$ & $2.022(9)$ \\
$\mathrm{N} 1-\mathrm{Zn}-\mathrm{N} 1{ }^{\circ}$ & $123.6(7)$ \\
$\mathrm{N} 1-\mathrm{Zn}-\mathrm{N} 2 /{ }^{\circ}$ & $104.9(2)$ \\
$\mathrm{N} 2-\mathrm{Zn}-\mathrm{N} 2{ }^{\circ}$ & $114.1(5)$ \\
$\mathrm{Zn}-\mathrm{N} 1(\mathrm{NCS}) / \AA$ & $1.929(11)$ \\
$\mathrm{Zn}-\mathrm{N} 2(\mathrm{bpp}) / \AA$ & $2.022(9)$ \\
$\mathrm{N} 1-\mathrm{Zn}-\mathrm{N} 1{ }^{\circ}$ & $123.6(7)$ \\
$\mathrm{N} 1-\mathrm{Zn}-\mathrm{N} 2 /{ }^{\circ}$ & $104.9(2)$ \\
\hline
\end{tabular}

\section{Conclusions}

In conclusion, several types of crystals having different colour (light blue, blue and red) were obtained in the synthesis of assembled complex of mixed crystals with three metals by solvent diffusion method. The formation mechanism of the assembled complexes bridged by 1,3-bis(4-pyridyl)propane is proposed on the basis of structure and colour modification. The red crystals have $2 \mathrm{D}$ interpenetrated structure. The samples of light-blue ionic crystals were $\left[\mathrm{H}_{2}(\mathrm{bpp})\right]\left[\mathrm{M}(\mathrm{NCS})_{4}\right]$ and they were built up spirally. The blue samples were $\mathrm{M}(\mathrm{NCS})_{2}(\mathrm{bpp})$ and they formed neutral $1 \mathrm{D}$ chain. $\left[\mathrm{H}_{2}(\mathrm{bpp})\right]\left[\mathrm{M}(\mathrm{NCS})_{4}\right]$ changed to $1 \mathrm{D}$ chain polymer $\left(\mathrm{M}(\mathrm{NCS})_{2}(\mathrm{bpp})\right)$ by releasing HNCS from the cation and anion in the reaction medium. The obtained complexes were characterized by ICP-AES, ESI-MS and X-Ray-diffraction methods.

\section{References}

1. Moulton, B.; Zaworotko, M.J. From molecules to crystal engineering: supramolecular isomerism and polymorphism in network solids. Chemical Reviews, 2001, 101, pp. 1629-1658.

2. Carlucci, L.; Ciani, G.; Proserpio, D.M.; Sironi, A. Interpenetrating diamondoid frameworks of silver(I) cations linked by N,N'-bidentatemolecular rods. Journal of the Chemical Society, Chemical Communications, 1994, pp. 2755-2756.

3. Gardner, G.B.; Venkataraman, D.; Moore, J.S.; Lee, S. Spontaneous assembly of a hinged coordination network. Nature (London), 1994, 374, pp. 792-795. 
4. Biradha, K.; Seward, C.; Zaworotko, M.J. Helical coordination polymers with large chiral cavities. Angewandte Chemie International Edition, 1999, 38, pp. 492-495.

5. Zheng, L.-M.; Fang X.; Lii, K.-H.; Song, H.-H.; Xin, X.-Q.; Fun, H.-K.; Chinnakali, K.; Razak, I.A. Syntheses, crystal structures and magnetic properties of two novel layered compounds: $\left[\mathrm{Fe}_{3}\left(\mathrm{C}_{2} \mathrm{O}_{4}\right)_{3}\left(4,4^{\prime} \text {-bpy }\right)_{4}\right]$ and $\left[\mathrm{Co}\left(\mathrm{C}_{2} \mathrm{O}_{4}\right)(4,4\right.$ '-bpy $\left.)\right](4,4$ '-bpy $=4,4$ '-bipyridine $)$. Journal of the Chemical Society, Dalton Transactions, 1999, pp. 2311-2316.

6. Carlucci, L.; Ciani, G.; Proserpio, D.M. A new type of supramolecular entanglement in the silver(I) coordination polymer $\left[\mathrm{Ag}_{2}(\text { bpethy })_{5}\right]\left(\mathrm{BF}_{4}\right)_{2}[$ bpethy $=1,2$-bis(4-pyridyl)ethyne $]$. Chemical Communications, 1999 , pp. 449-450.

7. Gudbjartson, H.; Biradha, K.; Poirier, K.M.; Zaworotko, M.K. Novel nanoporous coordination polymer sustained by self-assembly of T-shaped moieties. Journal of the American Chemical Society, 1999, 121, pp. 2599-2600.

8. Subramanian, S.; Zaworotko, M.J. Porous solids by design: $\left[\mathrm{Zn}\left(4,4^{\prime}-\text {-bpy }\right)_{2}\left(\mathrm{SiF}_{6}\right)\right]_{\mathrm{n}} \cdot \mathrm{xDMF}$, a single framework octahedral coordination polymer with large square channels. Angewandte Chemie, International Edition in English, 1995, 34, pp. 2127-2129.

9. Atsuchi, M.; Higashikawa, H.; Yoshida, Y.; Nakashima, S.; K. Inoue, K. Novel 2D interpenetrated structure and occurrence of the spin-crossover phenomena od assembled complexes, Fe(NCX) $(\mathrm{bpp})_{2}\left(\mathrm{X}=\mathrm{S}, \mathrm{Se}, \mathrm{BH}_{3}\right.$; bpp =1,3-bis(4-pyridyl)propane. Chemistry Letters, 2007, 36, pp. 1064-1065.

10. Atsuchi, M.; Inoue, K.; Nakashima, S. Reversible structural change of host framework triggered by desorption and adsorption of guest molecules in $\mathrm{Fe}(\mathrm{NCS})_{2}(\mathrm{bpp})_{2} \cdot 2$ (benzene) (bpp $=1,3$-bis(4-pyridyl)propane). Inorganica Chimica Acta, 2011, 370, pp. 82-88.

11. Nakashima, S.; Dote, H.; Atsuchi, M.; Inoue, I. Spin state of mixed crystals of iron with zinc or cobalt for the assembled complexes bridged by 1,3-bis(4-pyridyl)propanes. Journal of Physics: Conference Series. 2010, 217, 01035 .

12. Dote, H.; Nakashima, S. Crystal structure and spin state of mixed-crystals of iron with zinc and cobalt for the assembled complexes bridged by 1,3-bis(4-pyridyl)propanes. Hyperfine Interactions, 2012, 205, pp. 27-30.

13. Chen, H.-J.; Zhang, L.-Z.; Cai, Z.-G.; Yang, G.; Chen, X.-M. Organic-inorganic hybrid materials assembled through weak intermolecular interactions. Syntheses, structures and non-linear optical properties of $\left[4,4^{\prime}-\right.$-bipyH $\left._{2}\right]\left[\mathrm{M}\left(\mathrm{NCS}_{4}\right]\right.$ $\left(\mathrm{M}=\mathrm{Mn}^{2+}, \mathrm{Co}^{2+}\right.$, or $\mathrm{Zn}^{2+} ; 4,4^{\prime}$-bipy =4,4'-bipyridine $)$. Journal of the Chemical Society, Dalton Transactions, 2000, pp. 2463-2466.

14. Zhong, J.C.; Misaki, Y.; Munakata, M.; Kuroda-Sowa, T.; Maekawa, M.; Suenaga, Y.; Konaka, H. Silver(I) coordination polymer of 2,5-bis(4',5'-bis(methylthio)-1',3'-dithiol-2'-ylidene)-1,3,4,6-tetrathiapentalene (TTM-TTP) and its highly conductive iodine derivative. Inorganic Chemistry, 2001, 40, pp. 7096-7098. 